\title{
Gorontalo
}

Journal of Public Health

Volume 3 - No. 1 - April 2020

P-ISSN: 2614-5057, E-ISSN: 2614-5065

\section{Opini Remaja tentang Peringatan Kesehatan Bergambar dan Peraturan Daerah Kawasan Tanpa Rokok}

\section{Adolescents Opinion about Pictorial Health Warning and Smoke Free Area Regulation}

\author{
Ni Luh Putu Devhy*, Anak Agung Gde Oka Widana \\ Program Studi Rekam Medis dan Informasi Kesehatan, STIKes Wira Medika \\ Bali, Indonesia \\ *email: deevhy@gmail.com
}

\begin{abstract}
Pictorial health warnings (PHW)) and local regulations non-smoking areas (NSA) are among the government's efforts to reduce the prevalence of smoking. This study aims to describe adolescent opinions about PHW and Perda involving 158 samples. The sample was chosen by random sampling, the sample was teenagers who sat in junior high school. Data collection was done through structured interviews using questionnaires that have been tested before then analyzed descriptively. The average results of respondents were 13 years old, 57.6\% were women and 42.4\% were men. 93\% of respondents already knew of PHW and $89.2 \%$ saw PKB within 30 days. $94.9 \%$ of respondents said that $P W H$ made them concerned about the dangers of smoking, 94.3\% of respondents believed that PWH was more effective than written health warnings, and $97.5 \%$ of respondents supported implementing PWH. 90.5\% of respondents knew about the NSA regulation, $98.1 \%$ of respondents knew that schools were the NSA regional regulation area, 97.5\% respondents supported the implementation of the NSA regulation in all public areas, 97.5\% of respondents supported the government in enforcing the local regulation NSA in the room. In this study the five most frightening PWH images according to adolescents in the first position are lung cancer PWH. The results showed positive opinions and obtained support from adolescents to the regional regulation on smoke free area and $P H W$, so this can be used to develop a cigarette hazard control program.
\end{abstract}

Keywords: smoke free area; opinion; pictorial health warnings

\begin{abstract}
Abstrak
Peringatan kesehatan bergambar (PKB) dan peraturan daerah (PERDA) Kawasan tanpa rokok (KTR) merupakan salah satu upaya pemerintah yang dilakukan untuk menurunkan prevalensi merokok. Penelitian ini bertujuan untuk menggambarkan opini remaja tentang PKB dan Perda yang melibatkan 158 sampel. Sampel dipilih secara random sampling, sampel merupakan remaja yang duduk dibangku SMP. Pengumpulan data dilakukan melalui wawancara terstruktur dengan menggunakan kuisioner yang telah diuji sebelumnya kemudian dianalisis secara deskriptif. Hasil penelitian menunjukkan rerata responden berusia 13 tahun, 57,6\% adalah perempuan dan $42,4 \%$ adalah lakilaki. 93\% responden sudah tahu adanya PKB dan 89,2\% melihat PKB dalam 30 hari. 94,9\% responden mengatakan bahwa PKB membuat mereka peduli terhadap bahaya merokok, 94,3\% responden percaya bahwa PKB lebih efektif daripada peringatan kesehatan berupa tulisan, dan $97,5 \%$ responden mendukung PKB implementasi PKB. 90,5\% responden sudah tahu adanya Perda KTR, 98,1\% responden sudah tahu di sekolah merupakan kawasan Perda KTR,
\end{abstract}


97,5\% reponden mendukung implementasi Perda KTR di semua area tempat umum, 97,5\% responden mendukung pemerintah dalam menegakkan Perda KTR di dalam ruangan. Pada penelitian ini kelima gambar PKB yang paling menakutkan menurut remaja pada posisi pertama adalah PKB kanker paru. Hasil menunjukkan opini yang positif dan didapatkan dukungan remaja terhadap Perda KTR dan PKB, maka hal ini dapat digunakan untuk pengembangan program pengendalian bahaya rokok.

Kata kunci: kawasan tanpa rokok; opini; peringatan kesehatan bergambar

\section{PENDAHULUAN}

Kurangnya pemahaman remaja tehadap bahaya rokok merupakan salah satu penyebab peningkatan prevalensi merokok pada remaja di Indonesia. Berdasarkan data Riskesdas didapatkan bahwa prevalensi merokok pada remaja usia 10 sampai 18 tahun mengalami peningkatan sebesar 1,9\% dari tahun 2013 (7,2\%), ke tahun 2018 (9,10\%) (Kemenkes RI, 2018).

Udara bersih merupakan salah satu kebutuhan masyarakat pada umumnya, salah satu penyebab polusi udara disebabkan juga oleh asap rokok. Kawasan yang bebas dari asap rokok merupakan salah satu cara untuk melindungi remaja dari bahaya asap rokok orang lain. Merokok selain membahayakan diri sendiri juga dapat membahayakan orang disekitarnya atau disebut sebagai perokok pasif.

Pemerintah telah melakukan berbagai upaya untuk penanggulangan dampak rokok, salah satunya adalah melalui Peraturan Pemerintah Republik Indonesia nomor 109 tahun 2012 tentang pengamanan bahan yang mengandung zat adiktif berupa produk tembakau bagi kesehatan (Peraturan Pemerintah RI, 2012) dan untuk mendukung peraturan ini Menteri Kesehatan tahun 2013 mengeluarkan Permenkes no 28 tahun 2013 tentang pencantuman peringatan kesehatan dan informasi kesehatan pada kemasan produk tembakau (Permenkes, 2013). Pemerintah Daerah Provinsi Bali juga telah menetapkan Peraturan Daerah (Perda) no.10 tahun 2011 tentang KTR (Perda Provinsi Bali, 2011). Perda tersebut meliputi 7 kawasan yaitu area bermain anak, tempat umum, sarana kesehatan, tempat kerja, tempat belajar mengajar, tempat ibadah dan angkutan umum, di Bali Perda KTR sudah berlaku diseluruh Kabupaten. Perda KTR diharapkan dapat menjadi pilihan yang efektif dalam hal mengurangi perokok aktif di Provinsi Bali.

Berdasarkan penelitian yang telah terlebih dahulu menerapkan PKB terbukti efektif untuk berhenti merokok, di Singapura didapatkan hasil sebesar 25\%, $92 \%$ di Thailand dan 44\% di Kanada (Kemenkes RI, 2013). Berdasarkan penelitian yang telah dilakukan oleh Pradita dkk (2014) menyatakan bahwa adanya pengaruh positif peringatan kesehatan bergambar pada kemasan rokok terhadap motivasi perokok untuk berhenti merookok, hal ini dapat dijadikan alasan bahwa penelitian ini sangat penting untuk dilakukan pada remaja sehingga dapat memotivasi remaja untuk tidak merokok. Penelitian tentang PKB yang sudah lebih dahulu dilakukan mendapatkan hasil sebesar $87,9 \%$ percaya bahwa PKB lebih efektif dari pada peringatan kesehatan tertulis dan sebanyak 94,4\% mendukung implementasi PKB (Artawan dkk, 2015), dan untuk penelitian survei oponi mengenai kebijaksanaan KTR didapatkan hasil sebanyak 91,4\% responden mendukung dan sangat mendukung perda KTR, tetapi berdasarkan fasilitas beberapa responden memiliki jawaban yang berbeda beda (Artanti dkk, 2017). Penelitian ini bertujuan untuk menggambarkan opini remaja tentang PKB dan Perda KTR. 


\section{METODE}

Penelitian ini adalah penelitian observasional deskriptif dengan rancangan yang digunakan adalah cross sectional (survey) study. Penelitian dilaksanakan di Kota Denpasar, selama bulan Januari - Maret 2020. Populasi penelitian ini adalah remaja yang berada SMP Negri di Kota Denpasar yang berjumlah 959 siswa dan berumur 13 sampai dengan 15 tahun. Sampel berjumlah 158 responden. Jumlah sampel pada penelitian ini berdasarkan kesediaan responden untuk mengisi kuisioner.

Variabel yang dinilai aalam penelitian ini adalah variabel dukungan remaja terhadap implementasi PKB dengan cara ukur melalui wawancara menggunakan kuisioner, menggunakan 4 pertanyaan dan semua pertanyaan dihitung jumlah dan persentase (Sugiyono, 2011). Variabel kedua dalam penelitian ini adalah pengetahuan tentang peraturan KTR dan dukungan remaja terhadap implementasi KTR dengan cara ukur melalui wawancara menggunakan kuisioner, dengan 6 pertanyaan dan semua pertanyaan dihitung jumlah dan persentase (Sugiyono, 2011). Varibel ke 4, 5, 6, 7 dan 8 yaitu opini remaja terhadap rasa takut pada gambar yang ada di bungkus rokok dengan cara ukur melalui wawancara menggunakan kuisioner dengan dan setiap gambar diklasifikan dengan 4 kategori yaitu menakutkan, tidak menakutkan, cukup menakutkan, sangat menakutkan (Sugiyono, 2011). Data dikumpulkan dan kemudian dianalisis secara deskriptif. Penyajian data ditampilkan dalam bentuk tabel dan grafik serta dinarasikan.

\section{HASIL DAN PEMBAHASAN}

\section{Karakteristik Subyek Penelitian}

Gambaran karakteristik subjek penelitian ditunjukkan pada Tabel 1. Karakteristik responden dengan berjenis kelamin perempuan sebanyak 91 $(57,6 \%)$ responden, dan jenis kelamin laki-laki sebanyak $67(42,4 \%)$, sedangkan untuk umur 12 tahun sebanyak 41 responden $(25,9 \%)$ responden, umur 13 tahun sebanyak 78 responden (49,4\%), umur 14 tahun sebesar 32 responden $(20,3 \%)$, dan umur 15 tahun sebanyak 7 responden $(4,4 \%)$. Kelas VII sebanyak 62 responden $(39,2 \%)$, kelas VIII sebanyak 80 responden $(50,6 \%)$, dan kelas IX sebanyak 17 responden $(10,1 \%)$.

Tabel 1. Karakteristik Subyek Penelitian

\begin{tabular}{lcc}
\hline \multirow{2}{*}{ Karakteristik } & \multicolumn{2}{c}{ Jumlah } \\
\cline { 2 - 3 } & $\mathrm{n}$ & $\%$ \\
\hline Jenis Kelamin & & \\
Perempuan & 91 & 57,6 \\
Laki-laki & 67 & 42,4 \\
Umur & & \\
12 tahun & 41 & 25,9 \\
13 tahun & 78 & 49,4 \\
14 tahun & 32 & 20,3 \\
15 tahun & 7 & 4,4 \\
\hline Total & 158 & 100 \\
\hline
\end{tabular}

Masa remaja merupakan masa peralihan dari masa kanak-kanak ke masa dewasa yang mengalami perkembangan aspek atau fungsi untuk masuk ke masa dewasa. Pada rentang usia dari 12-15 tahun merupakan tahapan remaja sebelum memasuki dewasa hal ini menyebabkan remaja ingin mencoba-coba hal 
baru sehingga remaja sangat mudah terpengaruh oleh keadaan dan kebiasaan sekitar dan kebiasaan merokok (Notoadmodjo, 2007).

\section{Gambaran Dukungan Remaja terhadap Peringatan Kesehatan Bergambar}

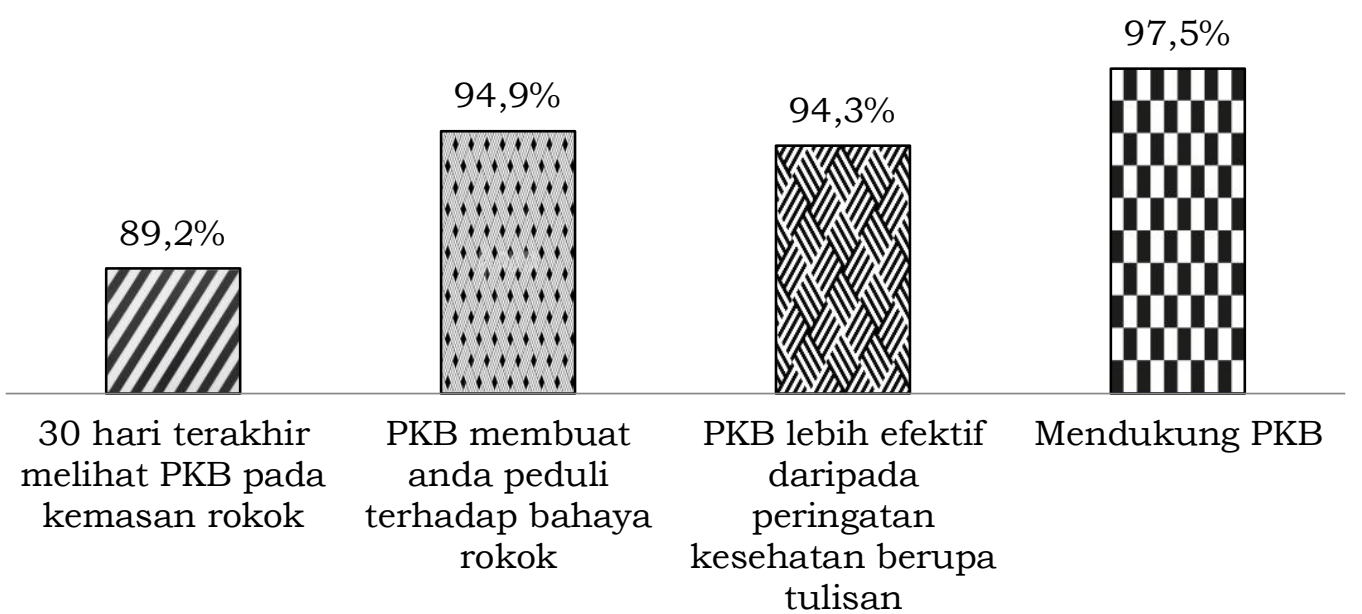

Gambar 1. Gambaran Dukungan Remaja terhadap Peringatan Kesehatan Bergambar di Kota Denpasar

Berdasarkan Gambar 1 penilaian terhadap dukungan terhadap PKB diketahui bahwa $89,2 \%$ responden sudah melihat PKB dalam 30 hari terakhir. 94,9\% responden mengatakan bahwa PKB membuat mereka peduli terhadap bahaya merokok dan 94,3\% responden percaya bahwa peringatan kesehatan bergambar lebih efektif dari pada peringatan kesehatan tertulis. 97,5\% responden mendukung implementasi PKB. Salah satu hasil penting dari penelitian ini mendapatkan lebih dari 97,5\% mendukung PKB dan sebagian besar remaja juga merasakan PKB lebih efektif dari peringatan kesehatan berupa tulisan. Hal ini sejalan dengan penelitian yang dilakukan di kota Gorontalo yang menyatakan bahwa sebanyak $85 \%$ remaja mendukung bila pictoria health warning dicantumkan dalam ukuran yang lebih besar (Sapiun dkk, 2017). Penelitian yang dilakukan di PKB yang lebih besar memberikan pengaruh yang lebih besar pula dan lebih efektif hal ini dapat memberi rasa takut pada remaja untuk merokok. Untuk itu kebijakan peringatan bergambar sebaiknya diteruskan dengan menggunakan gambar dalam kemasan rokok yang lebih besar.

\section{Gambaran Pengetahuan dan Dukungan Remaja terhadap Peraturan KTR}

Berdasarkan Gambar 2 tentang pengetahuan dukungan terhadap peraturan daerah kawasan tanpa rokok (Perda KTR) didapatkan 90,5\% telah mengetahui bahwa provinsi Bali sudah memiliki Perda KTR dan 98,1\% responden telah mengetahui bahwa di sekolah merupakan salah satu kawasan tanpa rokok (KTR). 97,5\% responden mendukung bahwa merokok harus dilarang di semua area tempat pendidikan dan $94,9 \%$ responden mendukung bahwa merokok harus dilarang di semua tempat umum. 97,5\% responden mendukung implementasi Perda KTR. 94,8 \% remaja memiliki peran penting untuk mendukung implemetasi Perda KTR.

Pengetahuan sikap dan dukungan remaja pada penelitian ini didapatkan hasil bahwa sebagian besar telah mengetahui keberadaan KTR di sekolah dan sebagian besar remaja mendukung KTR dilarang merokok di semua area 
pendidikan, di semua tempat umum dan mendukung pemerintah dalam menegakkan Perda KTR di Bali. Penelitian ini sejalan dengan penelitian yang dilakukan di Malang didapatkan hasil sebesesar 71\% mahasiswa mendukung adanya KTR di FIK UM (Ulfah dkk, 2018). Hal ini dikarenakan minat dan perhatian mereka tinggi dalam penerapan KTR sehingga dapat dijadikan contoh atau prioritas untuk mengawali dalam satu kampus pada jurusan kesehatan.

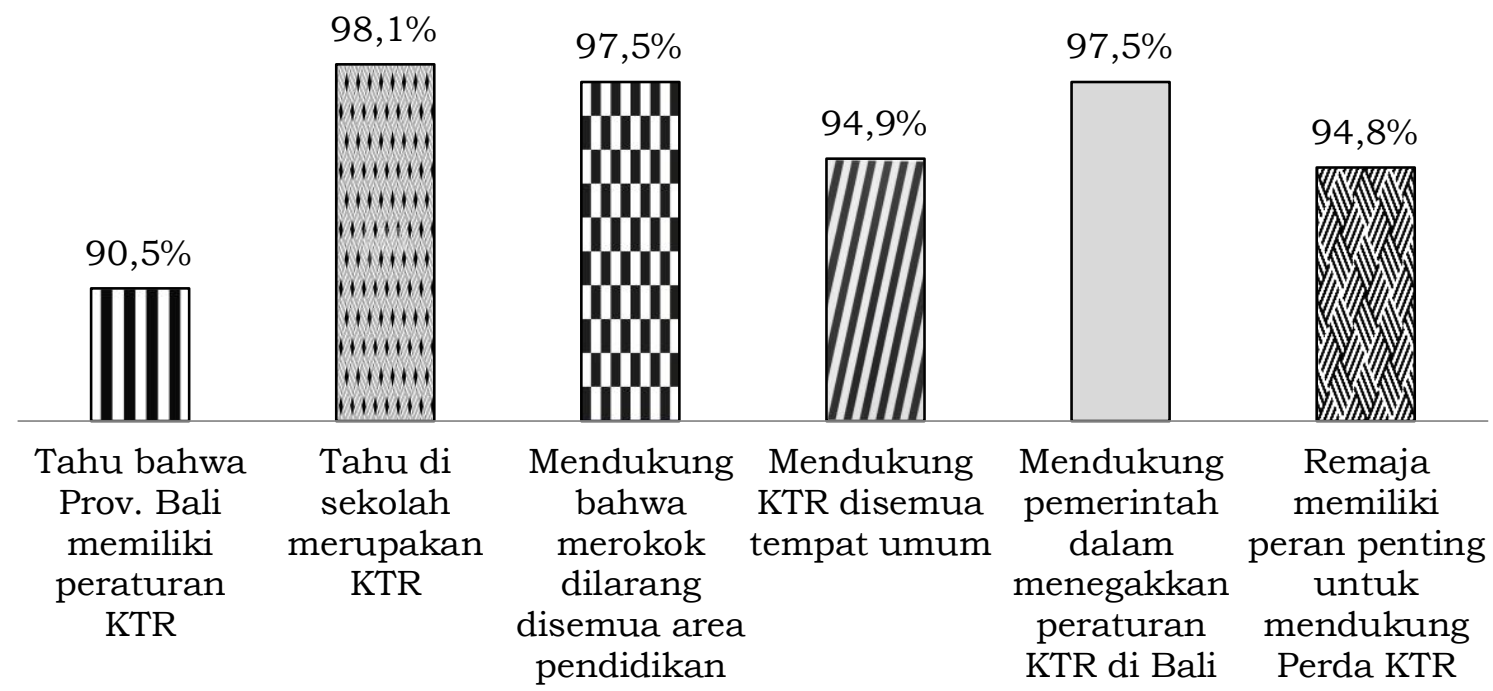

Gambar 2. Gambaran Pengetahuan dan Dukungan Remaja terhadap

Peraturan Kawasan Tanpa Rokok di Kota Denpasar

Berbeda halnya dengan penelitian yang dilakukan pada salah satu Universitas di Bali didapatkan hasil pada mahasiswa tentang pengetahuan KTR sebesar 45,3\% (Putra dan Widarsa, 2018). Perbedaan hasil ini membuktikan bahwa penerapan KTR harus dimulai sejak awal, penelitian ini berbanding terbalik dengan hasil penelitian yang didapatkan pada remaja. Berdasarkan hal tersebut dapat diambil kesimpulan bahwa penerepan KTR harus dimulai sejak awal untuk dapat memberikan pemahaman yang baik tentang KTR sehingga dapat memaksimalkan penerapan Perda KTR. Penerapan di SMP bisa digalang dari siswa agar mereka dapat mengawasi pelaksanaan KTR di lingkungan sekolahnya.

\section{Opini Remaja terhadap Pesan Kesehatan Bergambar (PKB)}
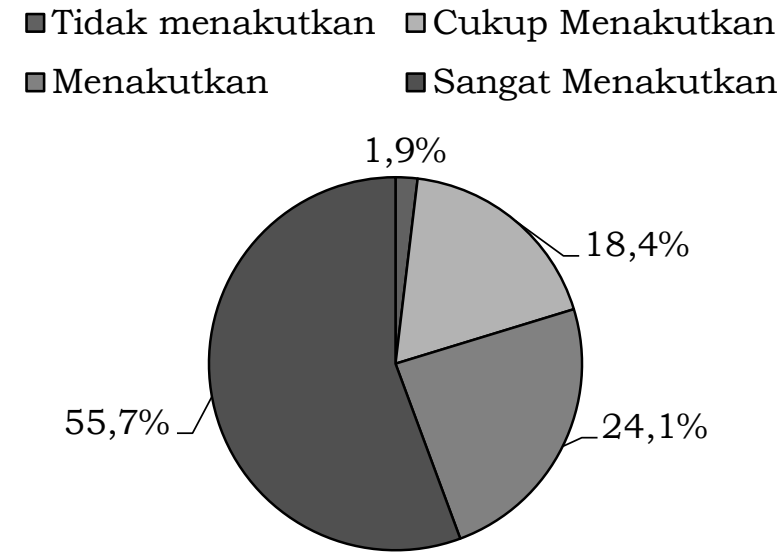

Gambar 3. Opini Remaja terhadap Peringatan Kesehatan Bergambar Kanker Tenggorokan 
Opini remaja terkait PKB kanker tenggorokan ditunjukkan pada Gambar 3. Opini remaja terhadap PKB kanker tenggorokan didapatkan hasil sebesar 1,9\% menyatakan tidak menakutkan, $24,1 \%$ menyatakan menakutkan, $18,4 \%$ menyatakan cukup menakutkan dan $55,7 \%$ menyatakan sangat menakutkan.

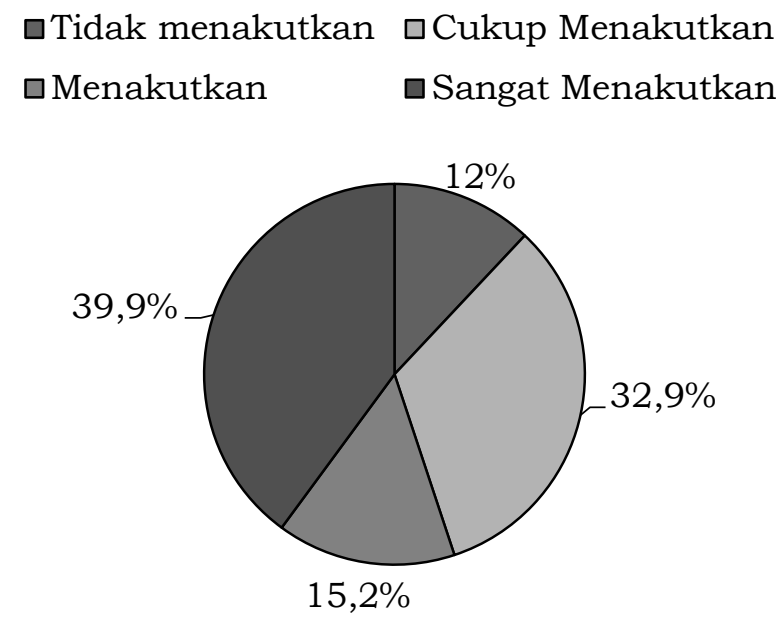

Gambar 4. Opini Remaja terhadap Peringatan Kesehatan Bergambar

Dekat dengan Anak Dapat Membahayakan

Berdasarkan Gambar 4 opini remaja terhadap PKB dekat dengan anak dapat membahayakan didapatkan hasil sebesar $12 \%$ tidak merasa takut, 15,2 \% merasa takut, 32,9\% menyatakan cukup takut dan 39,9\% menyatakan sangat takut. Makna dari Gambar 4 menunjukkan makna kekuatan, kemudian sesuatu yang misterius, juga bisa bermakna kegelapan, sesuatu yang kelam (Huda, 2017).
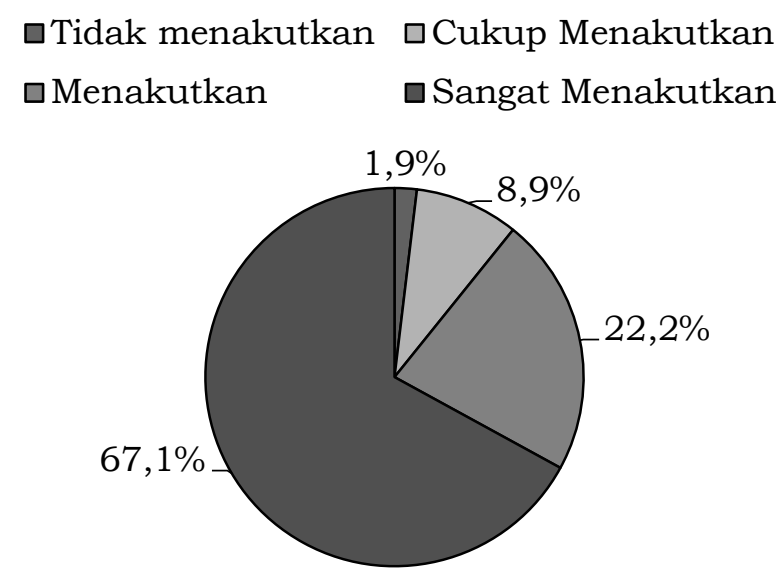

Gambar 5. Opini Remaja terhadap Peringatan Kesehatan Bergambar Kanker Mulut

Berdasarkan Gambar 5 opini remaja terhadap PKB kanker mulut didapatkan hasil sebesar 1,9\% menyatakan tidak takut, sebesar 22,2\% menyatakan menakutkan, sebesar 8,9\% menyatakan cukup menakutkan, dan sebesar $67,1 \%$ menyatakan sangat menakutkan.

Berdasarkan Gambar 6 tentang opini remaja terhadap PKB merokok membunuhmu didapatkan hasil sebesar $8,2 \%$ menyatakan tidak menakutkan, sebesar 21,5\% menyatakan menakutkan, sebesar 29,1\% menyatakan cukup menakutkan dan 41,1\% menyatakan sangat menakutkan. 

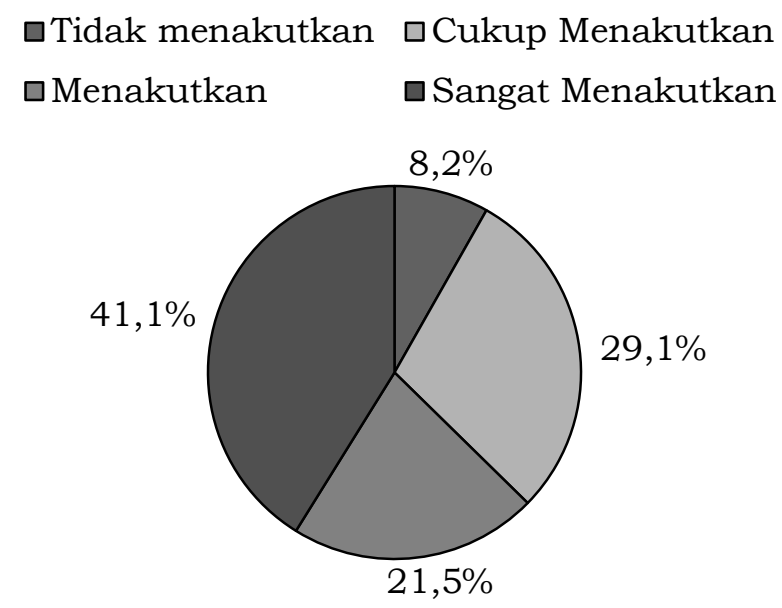

Gambar 6. Opini Remaja terhadap Peringatan Kesehatan Bergambar Merokok Membunuhmu

Berdasarkan Gambar 7 tentang opini remaja terhadap PKB kanker paru didapatkan hasil sebesar 1,3\% menyatakan tidak menakutkan, sebesar 18,4\% menyatakan menakutkan, sebesar 6,3\% menyatakan cukup menakutkan, dan sebesar $74,1 \%$ menyatakan sangat menakutkan.

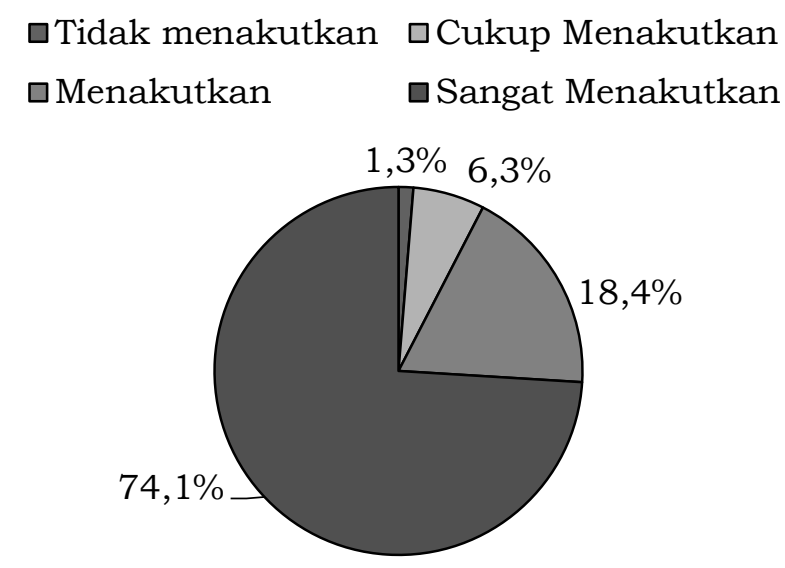

Gambar 7. Opini Remaja terhadap Peringatan Kesehatan Bergambar Kanker Paru

Opini remaja tentang PKB merupakan penilaian remaja sebagai responden dalam penilaian atas lima PKB. Hasil penilaian yang didapatkan pada penelitian ini bahwa PKB yang paling menakutkan adalah PKB kanker paru yaitu sebesar $74,1 \%$, kemudian urutan kedua PKB gambar kanker mulut dan ketiga adalah PKB kanker tenggorokan sedangkan untuk kedua PKB yang lainnya sebagian besar menyatakan cukup menakutkan. Hal ini sejalan dengan penelitian yang dilakukan di Kota Depok bahwa PKB yang paling menakutkan pada posisi pertama yaitu PKB kanker tenggorokan, posisi kedua yaitu kanker mulut dan posisi ketiga yaitu PKB kanker tenggorokan (Rahmawati dkk, 2018). Hasil penelitian lainnya didapatkan hampir semua responden menilai postif PKB tersebut, yang artinya responden remaja menilai kelima PKB tersebut sangat membantu perokok untuk berhenti merokok (Trisnowati dkk, 2018).

Dalam penyampaian informasi tentang bahaya merokok ternyata yang efektif adalah PKB kanker paru, PKB kanker tenggorokan, dan PKB kanker mulut sedangkan PKB membunuhmu dan PKB dampak asap merokok kurang efektif dalam penyampaian informasi tentang bahaya merokok. Untuk menanggulangi kurang efektifnya ke 2 gambar yang digunakan dalam PKB perlu diadakannya 
perbaikan atau penggantian dengan menggunakan gambar lain agar penyampaian informasi tentang bahaya merokok menjadi lebih efektif (Artawan $\mathrm{dkk}, 2015)$.

\section{PENUTUP}

Hasil opini yang positif dan mendapatkan dukungan remaja terhadap Perda KTR dan PKB, maka hal ini dapat digunakan untuk pengembangan program pengendalian bahaya rokok misalnya melaksanakan penyuluhan di sekolah yang berada di Kota Denpasar dengan menggunakan 5 gambar PKB untuk mencegah lebih banyak lagi perokok pemula, dan tetap melakukan sosialisasi di sekolah-sekolah untuk menambah wawasan remaja tentang kawasan tanpa rokok sehingga remaja bisa mendukung implementasi kebijakan Perda KTR. Untuk pihak sekolah dianjurkan melakukan sosialisasi tentang bahaya merokok, dan penegakan aturan yang tegas antara guru, siswa, satpam, sehingga terbentuknya komitmen lingkungan bebas asap rokok.

\section{UCAPAN TERIMA KASIH}

Terimaksih yang sebesar-besarnya kepada STIKes Wira Medika Bali yang telah memberikan dana untuk melaksanakan penelitian ini. Terimakasih kepada semua surveyor yang telah bekerja keras dalam pengumpulan data. Terimakasih serta apreasisasi setinggi-tingginya kepada semua responden atas kesediaannya untuk mengisi kuisioner.

\section{DAFTAR PUSTAKA}

Artanti KD, Martini S, Lestari KS, Widatic S, Megatsaric H. 2017. Survei Opini Publik dengan Perspektif Ketersediaan Sarana yang Bebas Asap Rokok di Surabaya. IPTEK Journal of Proceedings Series. 3(5): 2-6.

Artawan EPI, Astuti P, Duana I, Suarjana I, Mulyawan K, Bam T. 2015. Opini, Dukungan Masyarakat dan Efektivitas Peringatan Kesehatan Bergambar terhadap Upaya Berhenti Merokok Di Provinsi Bali. 2nd Indonesian Conference on Tobacco or Health. 4: 77-82.

Huda MS. 2017. Representasi Gambar Peringatan Kesehatan pada Kemasan Rokok. Jurnal Professional Fis Unived. 4.

Kemenkes RI. 2013. Pusat Promosi Kesehatan 2013 Peta Jalan Pengendalian Dampak Konsumsi Rokok Bagi Kesehatan. Jakarta: Kemenkes RI.

Kemenkes RI. 2018. Hasil Riskesdas 2018. Jakarta: Kemenkes RI.

Notoadmodjo. 2007. Promosi Kesehatan dan Ilmu Perilaku. Rineka Cipta. Jakarta.

Peraturan Pemerintah. 2012. Peraturan Pemerintah Republik Indonesia No. 109 Tahun 2012 tentang Pengamanan Bahan yang Mengandung Zat Adiktif Berupa Produk Tembakau Bagi Kesehatan. Lembaran Negara RI. Jakarta.

Peraturan Daerah. 2011. Peraturan Daerah Provinsi Bali No. 10 Tahun 2011 tentang Kawasan Tanpa Rokok. Denpasar.

Permenkes RI. 2013. Peraturan Menteri Kesehatan Republik Indonesia No. 28 Tahun 2013 tentang Pencantuman Peringatan Kesehatan dan Informasi Kesehatan pada Kemasan Produk Tembakau. Lembaran Negara RI. Jakarta.

Putra D dan Widarsa I. 2018. Tingkat Pengetahuan tentang Rokok dan Kawasan Tanpa Rokok Mahasiswa yang Merokok di Kampus. WMJ (Warmadewa Medical Journal). 3(1): 28-35.

Rahmawati AAD, Damayanti R, Anshari D. 2018. Persepsi Remaja terhadap Kesan Menakutkan pada Peringatan Kesehatan Bergambar Di Bungkus 
Rokok Ditinjau dari Extended Parallel Process. M. Perilaku dan Promosi Kesehatan. 1(1): 10-22.

Sapiun Z, Goi M, Herawati L. 2017. Persepsi Remaja Nonperokok terhadap Pictorial Health Warnings di Kota Gorontalo. Media Penelitian dan Pengembangan Kesehatan. 27(3): 141-152.

Pradita SA, Pradekso T, Setyabudi D, Herieningsih SW. 2014. Pengaruh Peringatan Kesehatan Bergambar pada Kemasan Rokok terhadap Motivasi Perokok untuk Berhenti Merokok. Interaksi Online. 2(2): 1-12.

Sugiyono. 2011. Metode Penelitian Pendidikan Kuantitatif Kualitatif. Alfabeta. Bandung.

Trisnowati H, Nabut OE, Marlinawati U. 2018. Persepsi terhadap Peringatan Kesehatan Bergambar pada Bungkus Rokok dan Perilaku Merokok Remaja di Yogyakarta. Jurnal Kedokteran dan Kesehatan. 14(2): 10-20.

Ulfah NH, Katmawanti S, Tama TD. 2018. Design Kawasan Tanpa Rokok (KTR) Fakultas Ilmu Keolahragaan Universitas Negeri Malang. Preventia: The Indonesian Journal of Public Health. 3(2): 162-174. 